Not only will the requisite new space thus be made available, but it will also be possible to achieve the segregation of the temperate species of the more arid environments from those which benefit by more humid conditions in a degree not previously possible.

When the present director of the Royal Botanic Gardens, Kew, was in Australia in 1949 and visited the various botanical centres in the Dominion, he found widespread interest and pleasure when the news of this project was made known, and this elicited spontaneous offers of further material. He brought back with him plants of the unique Cephalotus follicularis, which has pitcher leaves resembling those of Nepenthes, although the two families are in no degree related, and also specimens of that remarkable endemic Lycopodiaceous plant, Phylloglossum drummondii, which was found in a new locality.

The creation of a new post in the Herbarium, the occupant of which will be wholly concerned with the Australian flora, and the provision of this additional space for the culture of living material are important recognitions of the scientific significance of the vegetation of the Australian Commonwealth.

\section{ROWETT RESEARCH INSTITUTE EXTENSIONS TO BUILDINGS}

IN 1945, Dr. D. P. Cuthbertson succeeded Sir John Orr, now Lord Boyd-Orr, as director of the Rowett Research Institute, near Aberdeen. During the War, the Institute's investigations into problems of animal nutrition were greatly curtailed, and the new director's first task was to plan a long-term programme of research in the light of new developments in science and the economic conditions of Great Britain.

Nutrition is a meeting ground of many scientific disciplines, and to decide which of these should be represented in the Institute posed a difficult selection. The choice was influenced by what was desirable and by the men and women who were willing to interest themselves in nutritional research. After five years of steady development, the Institute now includes the following departments or sections: physiology, agricultural chemistry, protein and carbohydrate chemistry, enzyme chemistry, microbiological chemistry, pathology, bacteriology, helminthology, animal behaviour, sheep husbandry, pig husbandry, dairycattle husbandry, statistics, radiology and photography. It shares an experimental farm of about a thousand acres with the North of Scotland College of Agriculture and the facilities of its Reid Library with the Commonwealth Bureau of Animal Nutrition. The scientific staff, which numbered nineteen in 1939, has increased to forty-nine. This growth required new laboratory accommodation and considerable adaptation of existing laboratories, animal houses and byres. In view of the shortage of building materials and labour, an ingenious compromise was made between the desirable and the attainable. Until a year ago the laboratories were accommodated in a building with a flat roof which was in need of extensive repairs. To deal with this situation, $\mathrm{Mr}$. A. G. Ingham, chief architect of the Department of Agriculture for Scotland, produced an ingenious design for a new storey which would use the minimum of material, make the roof sound and provide new laboratories. This extension, now nearing completion, was formally opened on November 18 by Lord
Strathcona and Mount Royal, an old friend and generous benefactor of the Institute.

During the same week-end the activities of the Institute as a social and collegiate centre were also furthered by the opening of a new wing of nine bedrooms, a much desired extension of Strathcona House, which is the residential club in the grounds of the Institute. 'The formal opening of this extension was also done by Lord Stratheona. As a recognition of Lord Strathcona's many services to the Institute, he was presented with his portrait in oils, painted by Sir Oswald Birley. These ceremonies coincided with the annual reception and dinner in honour of the founders of the Institute.

\section{UNIVERSITY POPULATION OF GREAT BRITAIN}

IN its fourth report for the session 1950, the Committee of Public Accounts returns to a point made by the Committee in its third report for the session 1948-49, referring to the possibility of some more effective means of securing adequate Parliamentary control over the large grant-in-aid to universities and colleges in Great Britain, which has risen from $£ 1,680,000$ in $1932-33$ to $£ 17,564,500$ in $1949-50$ and $£ 23,284,150$ for $1950-51$. While in that report the Select Committee accepted the Treasury view that the grants need not be specifically authorized by statute and that it was not possible to present the estimates for the vote and the account in comparable form, it asked that the Treasury should consider whether, without impairing the independence of the universities, any further means could be adopted for informing Parliament how the grant-in-aid proposed in the estimate is to be spent.

In a minute of February 27, 1950, the Treasury referred to the publication of periodical reports by the University Grants Committee on university development, and of returns from the universities of financial and other statistics, and said that it was not clear what further steps could be taken to enable Parliament to judge of the wisdom with which the grants are used. Some support for this attitude is forthcoming from the publication of the "Returns from Universities and University Colleges in receipt of Treasury Grant, Academic Year 1948-49", recently issued*. When placed in comparison with the returns for the previous year, save in respect of Oxford and Cambridge, for which college incomes are excluded, the figures seem to supply reasonably adequate information. If this were supplemented, either in the returns or in reports from the University Grants Committee, by some more information about results obtained from certain of the larger non-recurrent earmarked grants for new developments, the substance of the Select Committee's criticism would seem to be met.

In justification of the Select Committee's observa. tions, it must be recognized that, leaving out of account college income, even at Cambridge 46 per cent and at Oxford 51 per cent of the total income of the university came from Parliamentary grants. The Treasury, however, has undertaken, when the present quinquennium for which the grants have been allocated ends in July 1952 and before future arrangements are settled, to make a very close review in

* University Grants Committee. Returns from Universities and University Colleges in receipt of Treasury Grant, Academic Yea. 1948-49. Pp. 26. (London: H.M. Stationery Office, 1950.) 2s. net. 
conjunction with the University Grants Committee of what has been achieved, and to examine in detail the question of possible extravagance. What must be avoided, however, is the sort of financial accountability which will endanger the originality and creative thought that the universities must safeguard at all costs and which would be a costly forfeit for saving a million or two of the taxpayers' money.

The income of the universities of Great Britain for the academic year $1948-49$ amounted to $£ 18,156,578$, of which $6 \cdot 7$ per cent was represented by endowments, 1.9 per cent by donations and subscriptions, 5 per cent by grants from local authorities, $59 \cdot 2$ per cent by Parliamentary grants, and $20 \cdot 6$ per cent by fees. The total income for English universities was $£ 14,588,360$, of which $£ 5,337,745$ was for London, $£ 1,664,926$ for Cambridge, $£ 1,332,674$ for Oxford and $£ 6,253,015$ for provincial universities and colleges. The total income for Wales was $£ 871,441$ and for Scotland $£ 2,696,777$. Compared with the previous year, total income rose by $£ 1,880,292$, chiefly by increases of $£ 1,338,923$ in Parliamentary grants and $£ 262,230$ in fees, which now represent $59 \cdot 2$ per cent and $20 \cdot 6$ per cent, respectively, of the total income. Income from endowments increased by $£ 18,166$.

Of the total expenditure of $£ 18,022,094$, the sum of $£ 323,305$ represented allocations to reserve, and the remainder was distributed as follows: administration, $9 \cdot 2$ per cent; departmental maintenance, $66 \cdot 3$ per cent; maintenance of premises, $11 \cdot 7$ per cent ; capital expenditure met from income, $2 \cdot 2$ per cent ; other maintenance expenditure, 10.6 per cent, the largest item under the last head being again the cost of the ordinary university examinations. Library expenditure totalled $£ 533,086$ for England, $£ 23,351$ for Wales and $£ 76,818$ for Scotland, approximately 3.6 per cent of the total expenditure, an increase of $£ 82,379$ on the previous year. No university deviated appreciably from this percentage; although in some of the London institutions the percentage reached more than 30, the average for all London institutions was 3.4. Figures for the three technical institutions shown were much lower, although that of 0.6 per cent for the Imperial College of Science and Technology appears to be attributed to ready access to the Science Library at the Science Museum. Of the total expenditure on libraries, $£ 340,298$ is on account of salaries and wages, $£ 162,091$ on account of books and $£ 64,774$ for periodicals. Only seven universities, Oxford (£28,328), Cambridge (£10,425), Birmingham $(£ 7,648)$, London $(£ 6,674)$, Edinburgh $(£ 6,524)$, Manchester $(£ 6,257)$ and Leeds $(£ 6,139)$ spent more than $£ 5,000$ on the purchase of books.

The full-time teaching staff increased from 6,536 to 7,390, and although the number of full-time students increased by 5,103 to 83,690 , there is thus a welcome increase in the ratio of staff to students. The increase in staff was made up of 85 professors, 563 lecturers, and 17 assistant lecturers and demon. strators, with a decrease of 7 in the number of readers, assistant professors and independent lecturers. Of the students, while there were 5,237 more men, there were 54 fewer women; although there was an increase of 204 women in Scotland. These were distributed as follows : arts, 44.4 per cent; pure science, $19 \cdot 2$ per cent; medicine, 16.8 per cent; technology, 13 per cent; agriculture, $3 \cdot 5$ per cent ; dentistry, $3 \cdot 1$ per cent. Of these 83,690 full-time students, 6,452 were engaged in research and other advanced work, 68,307 were reading for a first degree and 8,931 for a diploma; 61,554 were in England, 5,149 in Wales and 16,987 in Scotland, the English total comprising 15,082 at Oxford and Cambridge, 16,884 at London and 29,588 at provincial universities and colleges. Only at the University of Oxford was there a slight decrease in the number of full-time students. The proportion of full-time students residing in colleges and hostels was 22.7 per cent $(18.9$ per cent for men, 35.6 per cent for women), while $38 \cdot 2$ per cent were in lodgings and $39 \cdot 1$ per cent at home. Of overseas students from within the British Commonwealth, 3,335 were fulltime and 1,492 part-time; a further 2,589 full-time and 1,162 part-time students came from foreign countries. Cambridge again took 669 and Oxford 693 of these full-time students, Edinburgh 498, the London School of Economics 413 and University College, London, 375. A total of 24,826 full-time students was admitted for the first time during the year, an increase of 1,319 on 1947-48. There was little change in the general outlines of the distribution during the year; but there were 2,006 more men and 76 fewer women in arts, 575 more men and 159 more women in medicine and dentistry, 1,609 more men but 54 fewer women in pure science, 763 more men and 25 fewer women in technology and 284 more men but 58 fewer women in agriculture. Of the full-time students, $73 \cdot 7$ per cent were receiving assistance from Government departments, local authorities, universities or other bodies during the year, the percentage for England as a whole being 76, for Wales 81.8 and for Scotland $62 \cdot 9$. For the provincial universities, the figure $(78 \cdot 8)$ was slightly less than for either Cambridge $(79 \cdot 8)$ or Oxford $(81 \cdot 7)$, but higher than in the University of London $(66 \cdot 7)$.

Of the 18,180 part-time students, 4,335 were engaged in research or other advanced work, 2,171 were reading for a first degree and 2,826 for a diploma. Of such students engaged in advanced work 45.8 per cent were in medicine (including dentistry), 30.7 per cent in pure science and mathematics, $12 \cdot 6$ per cent in technology and 0.7 per cent in agriculture, a distribution contrasting markedly with that for fulltime advanced students of $37 \cdot 6$ per cent in pure science and mathematics, $9 \cdot 1$ per cent in medicine (including dentistry), and $3 \cdot 1$ per cent in agriculture, although the figure for technology $(13 \cdot 3$ per cent) is similar

\section{SCIENTIFIC CO-ORDINATION IN THE SOUTH PACIFIC}

$T$ HE welfare of the island peoples' in the South Pacific has become the objective of a six-nation co-ordinated undertaking known as the South Pacific Commission. Recognizing the mutual nature of many of the problems in the areas they administer, Australia, France, the Netherlands, New Zealand, the United Kingdom and the United States have joined in organizing the Commission to ". . . encourage and strengthen international co-operation in promoting the economic and social welfare and advancement of the peoples of the non-self-governing territories of the South Pacific region...." (Science, 3; May 26, 1950).

A research council has been established as an integral part of the Commission. Four specialists have been engaged to devote their full time to the undertaking, and other specialists will be retained to implement specific needs.

Projects to further the aims of the Commission are proposed after research by the council experts. They 